\title{
Characterization of Botrytis cinerea Isolates Present in Thompson Seedless Table Grapes in the Central Valley of Chile
}

Marcela Esterio, Departamento de Sanidad Vegetal, Facultad de Ciencias Agronómicas, Universidad de Chile, Código Postal 8820808, Santiago, Chile; Gastón Muñoz, Centro de Biotecnología del Gran Concepción. Facultad de Ciencias Biológicas, Universidad Andrés Bello, Sede Concepción, Autopista Concepción - Talcahuano 7100; and Cecilia Ramos, Gonzalo Cofré, Rodrigo Estévez, Andrea Salinas, and Jaime Auger, Departamento de Sanidad Vegetal, Facultad de Ciencias Agronómicas, Universidad de Chile, Código Postal 8820808, Santiago, Chile

\begin{abstract}
Esterio, M., Muñoz, G., Ramos, C., Cofré, G., Estévez, R., Salinas, A., and Auger, J. 2011. Characterization of Botrytis cinerea isolates present in Thompson seedless table grapes in the Central Valley of Chile. Plant Dis. 95:683-690.

Botrytis cinerea isolates from flowers and berries of Vitis vinifera 'Thompson seedless' (grapevine) were characterized in terms of two transposable elements (TEs) Boty and Flipper, random amplified polymorphic DNA (RAPD), infection levels, and resistance to iprodione. The isolates were collected from grapevines under fungicide programs of variable numbers of iprodione applications, and replicated in three Chilean Central Valley locations. Recovery was repeated from clusters collected at four phenological stages. Highest infection levels were found at bloom. Fungicide programs including one iprodione application or a combination of other fungicides were most effective for reducing gray mold symptoms. A total of 457 isolates collected from fungicide programs including only one iprodione application, and the control program, were tested for the presence of TEs. In all locations

TEs) were most common, followed by Boty. Vacuma isolates (containing neither TE) were identified at very low levels in two locations and only in the control treatment, and isolates with only Flipper were not detected at any time or location. Vacuma and Boty isolates were all sensitive to iprodione, while transposa isolates showed a wide range of resistance. Based on response to iprodione, the presence of TEs, and presence of vegetative-incompatibility alleles (Bc- $h c h)$, the isolates studied belong to $B$. cinerea Group II, a phylogenetic species within $B$. cinerea. Hierarchical analysis of molecular variance and genetic diversity analyses of the RAPD genotypes showed a genetic differentiation linked to location, but it was not related to geographic distance. Moreover, a genetic differentiation related to the phenological stage of grapes was also detected.
\end{abstract} and during all phenological stages, transposa isolates (containing both
Botrytis cinerea Pers.:Fr., the anamorph of Botryotinia fuckeliana (de Bary) Whetzel, is a necrotrophic fungus with a broad host range $(9,60)$. It infects hundreds of dicot plants, causing gray mold on many economically important crops such as vegetables, ornamentals, and fruit crops in subtropical areas of moderate temperature and high humidity (27). Gray mold causes considerable economic losses of Vitis vinifera (grapevine) in Chile, due to favorable environmental conditions and widespread planting of susceptible cultivars, such as Thompson seedless (45), the main table grape cultivar grown in the country (31).

$B$. cinerea populations are thought to be primarily clonal, due to both the abundance of conidia and the scarcity of sexual structures observed under field conditions $(27,37)$. However, this view has been totally revised during the last decade. $B$. cinerea exhibits considerable genetic and phenotypic diversity, due in part to its aneuploid status (15), and its ability to reshuffle genetic material through the processes of heterokaryosis (37) and parasexuality (15). In 1997, Giraud et al. (23) identified two groups of isolates, based on the presence or absence of two transposable elements (TEs), Boty and Flipper, in the B. cinerea genome. Isolates were named vacuma (those with neither TE) or transposa (those with both TEs). Both types of isolates are found in sympatry, but exhibit differences in their host range $(18,22,46,47)$, their genetic diversity (23), their different dominance as the grapevine develops $(23,41)$, and their conidial dimensions, growth rate, and fungicide resistance $(22,23)$. A third group of isolates harboring either Boty or

Corresponding author: Marcela Esterio, E-mail: mesterio@uchile.cl

Accepted for publication 1 February 2011.

doi:10.1094/PDIS-04-10-0298

(C) 2011 The American Phytopathological Society
Flipper has also been detected (10,22,38,40,44,47). Later studies, based on multiple gene genealogies, showed that $B$. cinerea is in fact a complex of at least two sibling species, called Groups I and II, which are currently described as phylogenetic species $(2,18$, 19,21). Group I consists entirely of vacuma isolates $(2,16,19$, 30,54), whereas Group II includes vacuma, transposa, Boty only, and Flipper only isolates $(1-3,10,40,44)$. Groups I and II also exhibit differences in conidial morphology, their relative frequencies during the grapevine growing season, natural resistance to fenhexamid, and host range $(18,19,41)$. Group II has been found to predominate in several crops in California (38), Tunisia (28), South Asia and Australia (26), and in grapes in vineyards of France (40) and Hungary (59).

Control of gray mold is based on an integration of several cultural methods with the use of fungicides belonging to several groups. Until the mid-1990s, chemical control of gray mold was mainly achieved by site-specific fungicides including benzimidazoles, dicarboximides, and $\mathrm{N}$-phenylcarbamates. Multispecific inhibitors such as chlorothalonil, dichlofluanid, and captan were used only in tank mixtures or in rotation with site-specific inhibitors, since the efficacy of the former group is relatively low when used alone (8). The intensive use of benzimidazole and dicarboximide fungicides has led to a rapid selection of resistant $B$. cinerea strains to one or both groups of fungicides (53). Isolates with low to high levels of dicarboximide resistance are reported from Chile and other grape-growing regions of the world (7,31).

Recently, new botryticides belonging to newly developed groups of fungicides with different modes of action were registered for use and introduced into fungicide programs. These new fungicides are the anilinopyrimidine-derivatives pyrimethanil and cyprodinil, the hydroxyanilide derivative fenhexamid, and the phenylpyrrole derivative fludioxonil (55). Cyprodinil has been registered in Chile and in many other countries and comes in prepacked mixtures with fludioxonil, as strains of $B$. cinerea with high or weak resistance to 
anilinopyrimidines have already been detected in grapes $(17,24$, 31,33).

An increased insensitivity of $B$. cinerea isolates is observed with exposure to phenylpyrrole fungicides and also to combinations of fungicides, a phenomenon referred to as multi-drug resistance. This is often associated with the action of ABC or MFS transporter proteins that export molecules outside the fungal cell and across the plasma membrane (11). Fenhexamid has been available for use in Chile against gray mold in grapes and vegetable crops since 1999. Despite a few reports of $B$. cinerea isolates with reduced sensitivity to fenhexamid in Chile (12), this fungicide is currently effective for control of gray mold $(6,32)$. Nonetheless, resistance to fungicides has been considered as one of the main factors involved in the failure of gray mold control programs. Dicarboximides are one of the most widely used groups of fungicides for gray mold of grape. In fact, the dicarboximide iprodione has been used for the past 20 years in Chile. Even so, the Chilean grapevine industry has botryticides with different modes of action registered for use in its spray programs, and the dicarboximides are the most widely used ones due to their popularity in many other grape-growing regions of the world, their high residue tolerance, and a short preharvest interval.

Despite the economic impact of gray mold on grapes, there is no detailed study of $B$. cinerea populations on grape in Chile. Such information can help develop more effective strategies to control and manage the disease $(35,43)$. Thus, the main objective of this work was to analyze the genetic structure of $B$. cinerea populations recovered from different phenological stages in the table grape $V$. vinifera 'Thompson seedless' during the 2000-2001 growing season, under the influence of fungicide programs with variable numbers of iprodione applications.

\section{Materials and Methods}

Control programs and locations. Seven fungicide programs were compared for control of gray mold on Thompson seedless. Fungicides were applied at the most critical periods of infection in Chilean vineyards: prebloom, full bloom, cluster closure, véraison, and preharvest. Program P1 was the control and included no fungicide applications. Programs P2 through P6 included different numbers of iprodione applications applied at different phenological stages (Table 1). Program P7 included only fungicides other than iprodione. Each program was applied to four replicates of a block of 12 vines (arranged in three adjacent rows of four consecutive vines); only the two central vines of each block were sampled. The experiment was replicated at three locations-Punitaqui $\left(30^{\circ} 50^{\prime}\right.$ South latitude), Buin ( $33^{\circ} 44^{\prime}$ South latitude), and Rengo ( $34^{\circ} 23^{\prime}$ South latitude)—in a completely random design. Distances among these locations are: Punitaqui-Buin $=460 \mathrm{~km}$, Punitaqui-Rengo $=$ $542 \mathrm{~km}$, and Buin-Rengo $=82 \mathrm{~km}$.

Determination of $B$. cinerea infection and rot levels. The efficacy of the fungicide programs was evaluated in terms of levels of infection and rot. For levels of infection, a total of 2,520 flowers or berries were examined per location at bloom, cluster closure, and véraison, and 2,240 clusters were examined per location at preharvest. Levels of infection at bloom, cluster closure, and véraison were determined in the laboratory. Samples of flowers or berries collected at these three phenological stages were incubated on water agar for up to 14 days at $20^{\circ} \mathrm{C}$, at which time the presence or absence of a $B$. cinerea colony was noted.

Preharvest levels of infection were determined directly in the field, based on the presence or absence of $B$. cinerea on at least one grape per cluster. The results were expressed as the percentage of flowers, berries, or clusters with $B$. cinerea compared to the total number of each type of plant material that was examined.

From each location at both evaluation periods, a total of 168 boxes ( 6 boxes $\times 4$ replicate blocks $\times 7$ programs) with $8.2 \mathrm{~kg}$ of net weight were harvested. Boxes were incubated at $0^{\circ} \mathrm{C}$ for 21,35 , and 45 days, and then berries with obvious signs of rot were weighed. Results were expressed as the percentage of the weight of the infected berries versus the total weight of the box $(8.2 \mathrm{~kg}$, net weight). To obtain $B$. cinerea isolates, rotted berries were incubated on water agar, and then isolates were transferred to potato dextrose agar for the monosporic isolation process.

Levels of infection and rot were transformed into degrees Bliss, and then they were subjected to the multiple comparison test (SNK), using Minitab (version 12, Minitab, Inc., State College, PA).

Iprodione resistance. Isolates of $B$. cinerea collected from different grapevines phenological stages in Punitaqui, Buin, and Rengo (466, 434, and 420 isolates, respectively) and treated with different fungicide programs were analyzed to evaluate iprodione resistance (Table 1). The resistance to iprodione (Rovral 4 Flo, 480 g liter ${ }^{-1}$ SC, Bayer CropScience Chile S.A.) was determined using the methods of Leroux and Gredt (34) and Leroux and Clerjeau (33). Briefly, each B. cinerea isolate was assayed in terms of its conidial germination percentage (GP) observed after incubation on glucose agar containing $10 \mu \mathrm{g} \mathrm{ml}^{-1}$ of iprodione. Isolates were classified as sensitive ( $\mathrm{S}: 0$ to $1 \% \mathrm{GP}$ ), slightly resistant (LR: 1 to $5 \%$ GP), moderately resistant (MR: 5 to $20 \%$ GP), or highly resistant (HR: > $20 \%$ GP).

DNA extraction and genetic characterization. Genomic DNA was extracted from selected isolates of $B$. cinerea using the method of Bainbridge et al. (4), as adapted by Muñoz et al. (47). A total of 457 isolates collected from P1 and P6 fungicide programs in Punitaqui, Buin, and Rengo (170, 143, and 144 isolates, respectively) were genetically characterized, determining the presence or absence of TEs Boty and Flipper and Bc-hch allele. Presence of TEs was done by a duplex polymerase chain reaction (PCR) assay as previously described (47), but some samples were also analyzed by PCR to detect TEs in separated reactions (47). Bc-hch allele was identified by PCR-restriction fragment length polymorphism (RFLP) (21) to classify isolates as representative of Group I or Group II.

Random amplified polymorphic DNA (RAPD) and genetic variability analysis. A total of 370 isolates collected from P1 and P6 fungicide programs in the three localities were analyzed with RAPD markers, varying the number of samples from 9 to 26 per phenological stage, location, and fungicide program.

RAPD was carried out using eight primers of the OPERON series (OPC-04, OPC-12, OPE-11, OPG-14, OPG-18, OPI-12, and OPR-02), as previously described by Muñoz et al. (47). DNA fragments were scored with the aid of a reference isolate included on

Table 1. Fungicide programs used for control of Botrytis cinerea on Vitis vinifera 'Thompson seedless'

\begin{tabular}{llllll}
\hline $\begin{array}{l}\text { Fungicide } \\
\text { programs }\end{array}$ & \multicolumn{5}{c}{ Phenological stages } \\
\cline { 2 - 5 } & Prebloom & Full bloom & Cluster closure & Véraison & Preharvest \\
\hline P1 & No application & No application & No application & No application & No application \\
P2 & Iprodione & Pyrimethanil & Captan & Fenhexamid & Pyrimethanil \\
P3 & Kresoxim-methyl & Iprodione & Captan & Fenhexamid & Pyrimethanil \\
P4 & Iprodione & Pyrimethanil & Captan & Iprodione & Pyrimethanil \\
P5 & Iprodione & Pyrimethanil & Captan & Iprodione & Iprodione \\
P6 & Kresoxim-methyl & Pyrimethanil & Captan & Fenhexamid & Iprodione \\
P7 & Kresoxim-methyl & Pyrimethanil & Captan & Fenhexamid & Pyrimethanil \\
\hline
\end{tabular}

${ }^{a}$ Fungicides were applied at the following concentrations of active ingredient: iprodione, 0.75 liter $\cdot \mathrm{ha}^{-1}$; pyrimethanil, 0.82 liter $\cdot \mathrm{ha}^{-1}$; captan, $2.4 \mathrm{~kg} \cdot \mathrm{ha}^{-1}$; fenhexamid, $0.6 \mathrm{~kg} \cdot \mathrm{ha}^{-1}$; kresoxim-methyl, 0.1 liter $\cdot \mathrm{ha}^{-1}$. 
each gel to ensure that all bands per locus were homologous. All polymorphic bands, i.e., those that were absent in at least one isolate, were included in the analysis. Genetic similarity using Jaccard's coefficients and phenogram construction were performed using the NTSYS-pv V2.0 software package (56). Population structure and differentiation were evaluated from a data set that included all haplotypes identified by RAPD markers. Total genetic variation was partitioned among locations, among phenological stages within locations, and among fungicide programs within locations, by performing a hierarchical analysis of molecular variance (AMOVA). Genetic differentiation between populations, defined as all isolates collected in a determined phenological stage, location, and fungicide program, was estimated by pairwise difference (Fst), and it was considered significant when the corresponding $P$ value was less than 0.05 . AMOVA and Fst were calculated using ARLEQUIN V3.11 (14). Gene diversity in the total population (isolates collected in a determined location within a fungicide program: $\mathrm{H}_{t}$ ) and within subpopulations (isolates collected in a determined phenological stage within a location and fungicide program: $\left.\mathrm{H}_{s}\right)(50)$, and the coefficient of genetic differentiation $\left[\mathrm{G}_{s t}\right.$ $\left.=\left(\mathrm{H}_{t}-\mathrm{H}_{s}\right) / \mathrm{H}_{t}\right](50)$ were calculated using POPGENE $1.31(61)$. Nei's unbiased measure of genetic distance (49) was estimated and used to construct a phenogram among populations using MEGA4 (58), with the unweighted pair group arithmetic mean averages (UPGMA) algorithm. The nonparametric statistical test of Mantel (57) was used for analyzing the correlation of Nei's genetic distance and geographic (linear) distance between populations, using the Mantel Nonparametric Test Calculator for Windows, version 2.00 (36).

\section{Results}

B. cinerea infection levels and control of gray mold. In the absence of fungicide applications, the highest infection levels were found at bloom, particularly in Punitaqui and Rengo and, to a lesser extent, in Buin (Fig. 1). These results indicate that this stage is the most critical one for control of infection. Punitaqui showed the highest infection levels at all phenological stages, thus this location can be considered as the one with the highest disease pressure.

The efficiency of the fungicide programs was evaluated at preand postharvest. Based on our preharvest evaluation, program P2 was the most effective in Rengo, whereas P6 and P7 were most effective in Buin and Punitaqui (Fig. 2A). Both P2 and P6 included a single iprodione application, and P7 consisted of fungicides other than iprodione (Table 1). Programs including more than one iprodione application were less effective, an observation more pronounced in Punitaqui and Buin (Fig. 2A). Based on our postharvest evaluation, programs including one iprodione application showed the lowest rot levels, as was the case based on our preharvest evaluation. Indeed, P2 was effective in all localities, P3 was effective in Punitaqui and Buin, and P6 was effective in Punitaqui and Rengo (Fig. 2B). Also consistent with our preharvest evaluation, P7 (a no-iprodione program) was one of the most effective at

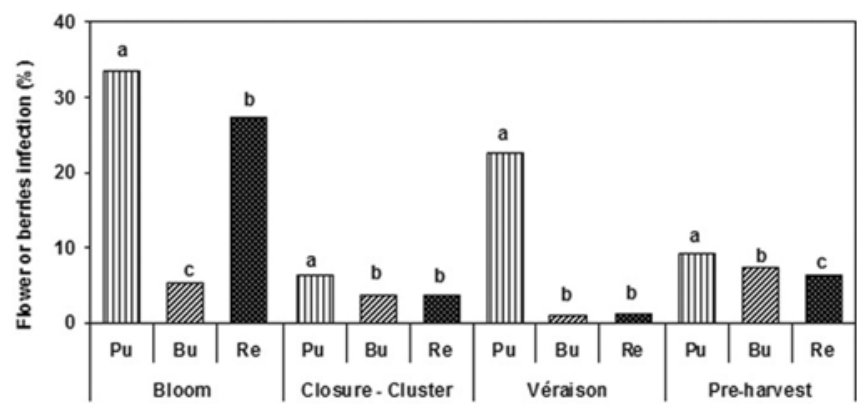

Fig. 1. Infection percentages of Botrytis cinerea in three locations and at phenological stages of grapevines subjected to program P1 (no fungicide application). Pu = Punitaqui; $\mathrm{Bu}=\mathrm{Buin} ; \mathrm{Re}=\mathrm{Rengo}$. Different letters indicate a significant difference according to the multiple comparison test (SNK) $(P<0.05)$. all three locations when evaluated at postharvest. In contrast, P4 and P5, which included two and three iprodione applications, respectively, showed the highest rot levels.

Resistance of $\boldsymbol{B}$. cinerea to iprodione. Highly resistant isolates were predominant (61 to $82 \%$ ), followed by sensitive isolates (15 to $32 \%$ ), whereas isolates belonging to the intermediate categories (low or moderate resistance) were scarcely present (1.3 to $6.5 \%$ and 4.7 to $10.4 \%$, respectively). No statistical differences were detected in the frequencies of isolates within the resistance categories among the different locations (Fig. 3).

TE genotypes, $B$. cinerea groups, and iprodione resistance. The transposa genotype was detected at a high frequency in all three locations (Table 2). There were three times as many Boty isolates as there were vacuma isolates ( 4.9 and $1.5 \%$, respectively), but both were much less common than transposa. Resistance to iprodione was differentially distributed among the TE genotypes. All vacuma and Boty isolates were sensitive to iprodione, except for one low-resistance Boty isolate. Conversely, $75.1 \%$ of trans-
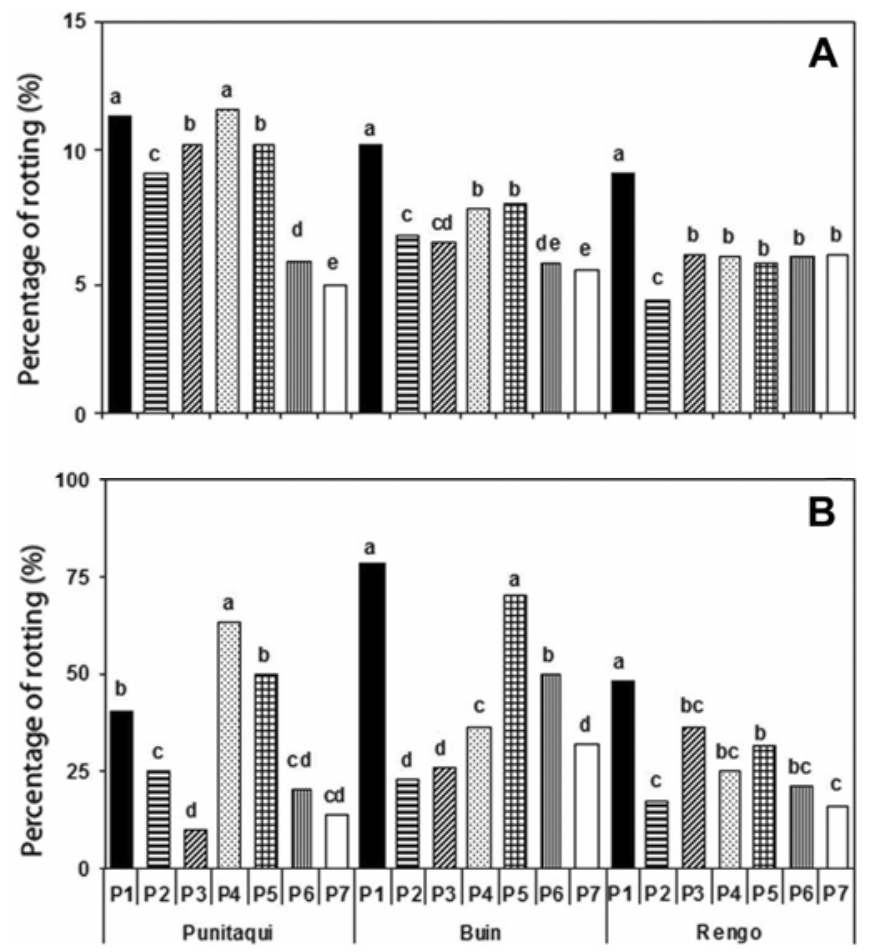

Fig. 2. Gray mold levels at three locations and under seven fungicide programs. A, preharvest; $\mathrm{B}$, postharvest without $\mathrm{SO}_{2}$. $\mathrm{P} 1=$ Program 1 (no fungicide applications); $\mathrm{P} 2=$ Program 2; $\mathrm{P} 3=$ Program 3; $\mathrm{P} 4=$ Program 4; P5 = Program 5; P6 = Program 6; P7 = Program 7. Different letters indicate a significant difference according to the multiple comparison test (SNK) $(P<0.05)$.

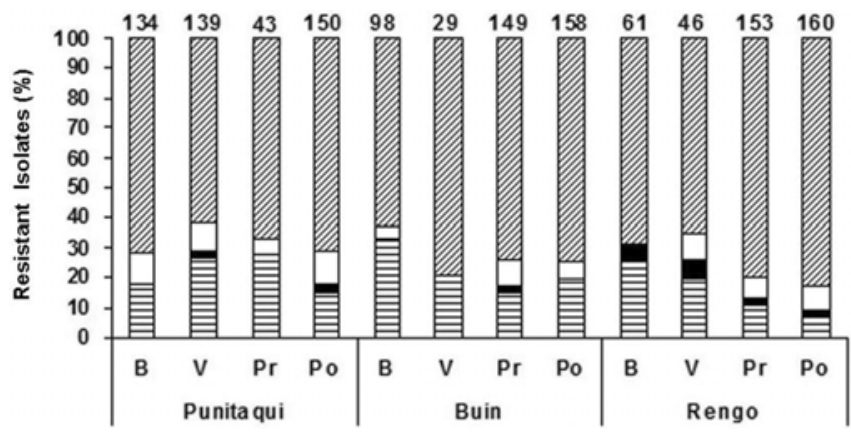

Fig. 3. Levels of resistance to iprodione of Botrytis cinerea isolates collected from different phenological stages of grapevines ( $\mathrm{B}$, bloom; $\mathrm{V}$, véraison; $\mathrm{Pr}$, preharvest; Po, postharvest) at three locations subjected to control program P1 (no fungicide applications). . Horizontal lines = sensitive; black = low resistance; white $=$ moderate resistance; diagonal lines $=$ high resistance. 
posa isolates were highly resistant (Table 2). Based on the presence of the Bc-hch2 allele, all isolates classified as Boty and vacuma (23 and 7, respectively) belong to B. cinerea Group II. The presence of the $\mathrm{Bc}-h c h 2$ allele in all transposa isolates is assumed, as transposa isolates Group I $(2,16,19,30,54)$.

Genetic diversity and population structure. Populations were highly variable, based on Jaccard similarity coefficients ranging from 0.26 to 0.98 per location (data not shown). However, UPGMA dendrograms did not show a clear pattern associated with location or phenological stage (data not shown).

Based on AMOVA with location as the grouping factor, most of the genetic variance was due to the variation within populations (77 and 13\% for within populations and among populations within location, respectively, Table 3), but the effect of location was indeed statistically significant $(10 \%, P<0.0001$, Table 3$)$. In contrast, differences among phenological stages or fungicide programs did not contribute significantly to total genetic variation.
The genetic differentiation due to location was also assessed by analysis of genetic diversity (Table 4). When all phenological stages and fungicide programs P1 and P6 were included in the analysis, the values of gene diversities $\left(\mathrm{H}_{\mathrm{t}}\right)$ within each location were comparable ( 0.2251 to 0.2573 ; Table 4$)$, but were lower than the value determined across all three locations ( 0.2715 ; Table 4$)$. However, the values found for the coefficient of genetic differentiation (Gst) of each location were higher than, or comparable to, the value determined across all three locations $(0.1003$ to 0.2232 versus 0.1011, Table 4). The dendrogram based on Nei's genetic distance did not show a clear clustering linked to location, except for populations collected at the postharvest stage (data not shown). Thus, when only these latter populations were considered in the analyses, the gene diversity across all three locations was higher than gene diversity within each location (Table 4). Thus, for isolates collected at the postharvest stage, the coefficient of genetic differentiation across all three locations, those of each location

Table 2. Levels of sensitivity to iprodione of Botrytis cinerea isolates recovered from grapevines treated with no fungicides (program P1, control)

\begin{tabular}{|c|c|c|c|c|c|c|c|c|c|c|}
\hline \multirow[b]{3}{*}{ Location } & \multirow[b]{3}{*}{ Stage } & \multirow[b]{3}{*}{ Plant material } & \multicolumn{8}{|c|}{ Genotyped isolates resistant to iprodione } \\
\hline & & & \multirow{2}{*}{$\begin{array}{c}\text { Number } \\
\text { of isolates }\end{array}$} & \multicolumn{4}{|c|}{ transposa } & \multirow{2}{*}{$\frac{\text { Boty }}{\text { S }}$} & \multicolumn{2}{|c|}{ vacuma } \\
\hline & & & & $\mathbf{S}^{\mathbf{a}}$ & LR & MR & HR & & $\mathbf{L R}$ & $\mathbf{S}$ \\
\hline \multirow[t]{4}{*}{ Punitaqui } & Bloom & Flowers & 60 & 4 & 0 & 11 & 39 & 4 & 0 & 2 \\
\hline & Véraison & Berries & 48 & 6 & 1 & 6 & 33 & 0 & 0 & 2 \\
\hline & Preharvest & Berries & 5 & 2 & 0 & 0 & 3 & 0 & 0 & 0 \\
\hline & Postharvest & Berries & 57 & 3 & 2 & 3 & 49 & 0 & 0 & 0 \\
\hline \multirow[t]{4}{*}{ Buin } & Bloom & Flowers & 21 & 1 & 0 & 1 & 13 & 4 & 0 & 2 \\
\hline & Véraison & Berries & 6 & 0 & 0 & 0 & 6 & 0 & 0 & 0 \\
\hline & Preharvest & Berries & 59 & 6 & 1 & 5 & 44 & 3 & 0 & 0 \\
\hline & Postharvest & Berries & 57 & 10 & 0 & 4 & 37 & 5 & 0 & 1 \\
\hline \multirow[t]{5}{*}{ Rengo } & Bloom & Flowers & 13 & 1 & 1 & 0 & 10 & 1 & 0 & 0 \\
\hline & Véraison & Berries & 12 & 1 & 0 & 3 & 8 & 0 & 0 & 0 \\
\hline & Preharvest & Berries & 59 & 2 & 0 & 4 & 51 & 2 & 0 & 0 \\
\hline & Postharvest & Berries & 60 & 5 & 0 & 2 & 50 & 2 & 1 & 0 \\
\hline & & Total & 457 & 41 & 5 & 39 & 343 & 21 & 1 & 7 \\
\hline
\end{tabular}

${ }^{a}$ Iprodione sensitivity levels: S, sensitive; LR, low resistance; MR, medium resistance; HR, high resistance.

Table 3. AMOVA results of Botrytis cinerea populations with location, phenological stages, and fungicide programs as grouping factors

\begin{tabular}{|c|c|c|c|c|c|}
\hline Source of variation & df & Sum of squares & $\begin{array}{l}\text { Variance } \\
\text { components }\end{array}$ & $\begin{array}{c}\text { Variation } \\
(\%)\end{array}$ & $P$ value \\
\hline Among locations & 2 & 238,982 & 0.74713 & 10.09 & $<0.0001$ \\
\hline Among populations within locations & 14 & 372,955 & 0.98111 & 13.25 & $<0.0001$ \\
\hline Within populations & 353 & $2,003,925$ & 567.684 & 76.66 & $<0.0001$ \\
\hline Total & 369 & $2,615,862$ & 731.590 & 100.00 & \\
\hline Among stages & 3 & 131,820 & 0.05242 & 0.73 & 0.2512 \\
\hline Among populations within stages & 13 & 480,118 & 146.545 & 20.37 & $<0.0001$ \\
\hline Within populations & 353 & $2,003,925$ & 567.684 & 78.90 & $<0.0001$ \\
\hline Total & 369 & $2,615,862$ & 719.471 & 100.00 & \\
\hline Among programs & 1 & 17,029 & -0.14513 & -2.04 & 0.9325 \\
\hline Among populations within programs & 15 & 594,909 & 158.168 & 22.24 & $<0.0001$ \\
\hline Within populations & 353 & $2,003,925$ & 567.684 & 79.80 & $<0.0001$ \\
\hline Total & 369 & $2,615,862$ & 711.339 & 100.00 & \\
\hline
\end{tabular}

Table 4. Genetic diversity analyses of populations of Botrytis cinerea sampled at three locations and two control programs (P1 and P6)

\begin{tabular}{|c|c|c|c|c|c|}
\hline Population & No. of subpopulations & Sample size & $\mathbf{H}_{t}^{\mathbf{a}}$ & $\mathbf{H}_{s}^{\mathbf{b}}$ & $\mathbf{G}_{s t}{ }^{c}$ \\
\hline \multicolumn{6}{|c|}{ Considering all stages } \\
\hline Punitaqui & 6 & 148 & 0.2573 & 0.2142 & 0.1675 \\
\hline Buin & 6 & 125 & 0.2466 & 0.1916 & 0.2232 \\
\hline Rengo & 5 & 97 & 0.2251 & 0.2025 & 0.1003 \\
\hline All localities & 17 & 370 & 0.2715 & 0.2440 & 0.1011 \\
\hline \multicolumn{6}{|c|}{ Considering postharvest only } \\
\hline Punitaqui & 2 & 50 & 0.2242 & 0.2138 & 0.0466 \\
\hline Buin & 2 & 51 & 0.2360 & 0.2222 & 0.0585 \\
\hline Rengo & 2 & 51 & 0.2237 & 0.2156 & 0.0363 \\
\hline All localities & 6 & 152 & 0.2647 & 0.2280 & 0.1388 \\
\hline
\end{tabular}

${ }^{a}$ Gene diversity in the total population as described by Nei (50).

${ }^{\mathrm{b}}$ Gene diversity within populations as described by Nei $(50)$.

${ }^{c}$ Coefficient of genetic differentiation $\mathrm{G}_{s t}=\left(\mathrm{H}_{t}-\mathrm{H}_{s}\right) / \mathrm{H}_{t}$ as described by Nei (50). 
( 0.1388 versus 0.0363 to 0.0585 , respectively, Table 4B), and a dendrogram based on Nei's genetic distance (Fig. 4) showed a differentiation related to location. However, as shown in Figure 4, populations from distant localities (Punitaqui-Rengo, $545 \mathrm{~km}$ apart) were genetically more closely related to each other than those geographically nearer (Buin-Rengo, $82 \mathrm{~km}$ apart). Further evidence of a lack of a relationship between genetic distance and geographic distance comes from the fact that the regression between Nei's genetic distance and geographic distance was significant according to the Mantel test, based on a $g$ value $(0.5151)$ that

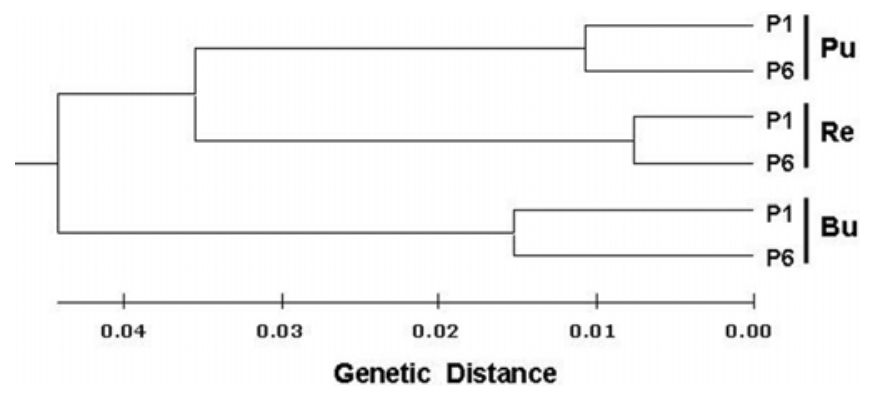

Fig. 4. Dendrogram of genetic distances among subpopulations of Botrytis cinerea collected at the postharvest stage under two fungicide programs ( $P 1$ and $P 6)$ in three locations ( $\mathrm{Pu}=$ Punitaqui; $\mathrm{Re}=$ Rengo; and $\mathrm{Bu}=$ Buin). was less than the critical value of 1.645 , at the $5 \%$ level of significance.

The effect of the phenological stages and control program on the population structure on each region was tested by AMOVA, analyzing the RAPD data obtained from Punitaqui and Buin populations separately. As shown in Table 5, the contribution of stages and control programs to the genetic variance was low (about $12 \%$ in both locations for stages and 6 and $8 \%$ in Punitaqui and Buin for programs), but it was significant for programs. However, when control program was used as the grouping factor, the variance was negative and the effect of phenological stages increased (from 12 to $19 \%$ and $22 \%$ in Punitaqui and Buin, respectively) and was statistically significant.

To evaluate the effect of fungicide program on the population structure, the data obtained at each location and at every phenological stage was examined by AMOVA. These analyses showed a contribution of fungicide programs of 7.5 to $12 \%$ on the genetic variance, which was significant in Punitaqui at bloom and at preand postharvest in Buin (data not shown). These findings suggest that the genetic differences among phenological stages are higher than differences among fungicide programs.

The pairwise $F$ statistics (Fst) showed a high genetic differentiation between populations (Table 6). In fact, Fst values ranged from 0.007 to 0.416 in the whole population, with Buin being more variable than Punitaqui ( 0.06 to 0.32 and 0.04 to 0.25 , respectively; Table 6). Rengo showed the lowest Fst values (0.007 to 0.11). Pairs

Table 5. AMOVA results of Botrytis cinerea populations with phenological stages and control programs as grouping factor at two fixed locations

\begin{tabular}{|c|c|c|c|c|c|c|}
\hline Locations & Source of variation & df & Sum of squares & Variance components & Variation (\%) & $P$ value \\
\hline \multirow[t]{8}{*}{ Punitaqui } & Among stages & 2 & 118.460 & 0.86444 & 12.26 & 0.0919 \\
\hline & Among programs within stages & 3 & 48.953 & 0.42614 & 6.04 & $<0.0001$ \\
\hline & Within stages & 143 & 823.895 & 5.76151 & 81.70 & $<0.0001$ \\
\hline & Total & 148 & 991.309 & 7.05208 & 100.00 & \\
\hline & Among programs & 1 & 17.713 & 0.26762 & -3.95 & 0.8211 \\
\hline & Among stages within programs & 4 & 149.701 & 1.27810 & 18.87 & $<0.0001$ \\
\hline & Within programs & 143 & 823.895 & 5.76151 & 85.08 & $<0.0001$ \\
\hline & Total & 148 & 991.309 & 6.77198 & 100.00 & \\
\hline \multirow[t]{8}{*}{ Buin } & Among stages & 2 & 105.535 & 0.90680 & 12.92 & 0.0762 \\
\hline & Among programs within stages & 3 & 53.944 & 0.60050 & 8.55 & $<0.0001$ \\
\hline & Within stages & 119 & 656.113 & 5.51356 & 78.53 & $<0.0001$ \\
\hline & Total & 124 & 815.592 & 7.02086 & 100.00 & \\
\hline & Among programs & 1 & 20.493 & -0.32166 & -4.81 & 0.7028 \\
\hline & Among stages within programs & 4 & 138.986 & 1.49657 & 22.38 & $<0.0001$ \\
\hline & Within programs & 119 & 656.113 & 5.51356 & 82.43 & $<0.0001$ \\
\hline & Total & 124 & 815.592 & 6.68846 & 100.00 & \\
\hline
\end{tabular}

Table 6. Pairwise $F$ statistics (Fst) between isolates of Botrytis cinerea collected from table grapes in different locations, at different phenological stages, and in different control programs (Prog)

\begin{tabular}{|c|c|c|c|c|c|c|c|c|c|c|c|c|c|c|c|c|c|c|c|}
\hline \multirow[b]{3}{*}{ Locations } & \multirow[b]{3}{*}{ Stages } & \multirow[b]{3}{*}{ Prog } & \multicolumn{6}{|c|}{ Punitaqui } & \multicolumn{6}{|c|}{ Buin } & \multicolumn{5}{|c|}{ Rengo } \\
\hline & & & \multicolumn{2}{|c|}{ Bloom } & \multicolumn{2}{|c|}{ Véraison } & \multicolumn{2}{|c|}{ Postharvest } & \multicolumn{2}{|c|}{ Bloom } & \multicolumn{2}{|c|}{ Véraison } & \multicolumn{2}{|c|}{ Postharvest } & \multirow{2}{*}{$\frac{\text { Bloom }}{\text { P6 }}$} & \multirow{2}{*}{$\frac{\text { Véraison }}{\text { P6 }}$} & \multirow{2}{*}{$\begin{array}{c}\text { Preharv } \\
\text { P6 }\end{array}$} & \multicolumn{2}{|c|}{ Postharv } \\
\hline & & & P1 & P6 & P1 & P6 & P1 & P6 & P1 & P6 & P1 & P6 & P1 & P6 & & & & P6 & P1 \\
\hline \multirow[t]{6}{*}{ Punitaqui } & Bloom & $\mathrm{P} 1$ & 0.000 & & & & & & & & & & & & & & & & \\
\hline & & P6 & 0.106 & 0.000 & & & & & & & & & & & & & & & \\
\hline & Véraison & $\mathrm{P} 1$ & 0.250 & 0.242 & 0.000 & & & & & & & & & & & & & & \\
\hline & & P6 & 0.114 & 0.088 & 0.048 & 0.000 & & & & & & & & & & & & & \\
\hline & Postharv & $\mathrm{P} 1$ & 0.259 & 0.253 & 0.156 & 0.150 & 0.000 & & & & & & & & & & & & \\
\hline & & P6 & 0.219 & 0.195 & 0.091 & 0.102 & 0.052 & 0.000 & & & & & & & & & & & \\
\hline \multirow[t]{6}{*}{ Buin } & Bloom & $\mathrm{P} 1$ & 0.378 & 0.416 & 0.223 & 0.220 & 0.284 & 0.297 & 0.000 & & & & & & & & & & \\
\hline & & P6 & 0.370 & 0.995 & 0.260 & 0.249 & 0.238 & 0.290 & $0.103^{\mathrm{a}}$ & 0.000 & & & & & & & & & \\
\hline & Véraison & $\mathrm{P} 1$ & 0.326 & 0.331 & 0.211 & 0.191 & 0.206 & 0.248 & 0.237 & 0.261 & 0.000 & & & & & & & & \\
\hline & & P6 & 0.296 & 0.294 & 0.192 & 0.181 & 0.107 & 0.165 & 0.177 & 0.192 & 0.124 & 0.000 & & & & & & & \\
\hline & Postharv & $\mathrm{P} 1$ & 0.116 & 0.114 & 0.153 & 0.076 & 0.234 & 0.173 & 0.324 & 0.315 & 0.225 & 0.255 & 0.000 & & & & & & \\
\hline & & P6 & 0.190 & 0.168 & 0.151 & 0.080 & 0.145 & 0.162 & 0.248 & 0.240 & 0.068 & 0.136 & 0.076 & 0.000 & & & & & \\
\hline \multirow[t]{5}{*}{ Rengo } & Bloom & P6 & 0.274 & 0.258 & 0.292 & 0.199 & 0.115 & 0.215 & 0.360 & 0.277 & 0.192 & 0.146 & 0.255 & 0.119 & 0.000 & & & & \\
\hline & Véraison & P6 & 0.350 & 0.330 & 0.287 & 0.238 & 0.176 & 0.260 & 0.397 & 0.369 & 0.245 & 0.203 & 0.307 & 0.195 & $0.093^{\mathrm{a}}$ & 0.000 & & & \\
\hline & Preharv & P6 & 0.260 & 0.234 & 0.281 & 0.218 & 0.125 & 0.187 & 0.390 & 0.317 & 0.264 & 0.210 & 0.236 & 0.166 & $0.008^{\mathrm{a}}$ & 0.112 & 0.000 & & \\
\hline & Postharv & P6 & 0.313 & 0.312 & 0.304 & 0.251 & 0.163 & 0.250 & 0.383 & 0.346 & 0.254 & 0.208 & 0.309 & 0.203 & $0.041^{\mathrm{a}}$ & 0.112 & 0.068 & 0.000 & \\
\hline & & $\mathrm{P} 1$ & 0.281 & 0.266 & 0.250 & 0.210 & 0.118 & 0.180 & 0.331 & 0.263 & 0.237 & 0.177 & 0.253 & 0.169 & $0.035^{\mathrm{a}}$ & 0.082 & $0.024^{\mathrm{a}}$ & $0.031^{\mathrm{a}}$ & 0.000 \\
\hline
\end{tabular}

a Values are not significant $(P>0.05)$. 
of populations from different regions showed high Fst values, especially those collected at bloom. These results agree with those previously found by AMOVA.

\section{Discussion}

B. cinerea Group II is present in Thompson seedless table grapes in the Central Valley of Chile. This study is the first attempt to characterize genetically $B$. cinerea populations from table grapes in Chile. Our first finding, that only Group II isolates were identified in three Thompson seedless vineyards at all phenological stages, suggests that Chilean vineyard populations of $B$. cinerea are made up exclusively of Group II. In fact, we found that $94 \%$ of the 457 isolates genotyped were transposa, thus falling into the Group II category. The remaining fraction of the population, 5\%, was made up by Boty only, while $1 \%$ was vacuma. All of the 29 isolates belonging to the last two genotypes carried the $\mathrm{Bc}-h c h 2$ allele, thus clearly indicating their categorization into Group II. Our results support a previous report in which all of the 472 isolates collected from different table grape cultivars in 13 locations in Chile carry the Bc-hch 2 allele (14). The predominance of Group II on grapevines has been reported from France $(23,42,43)$, Hungary $(59)$, Italy, Croatia (10), and Tunisia (28). The same finding was reported from B. cinerea from several crops in South Asia and Australia (26). Group I seems to be strongly underrepresented also in field crops in California (1.7\%) (38) and France (2.5 to 5\%) $(18,41)$. The presence of $B$. cinerea Group I isolates in other crops in Chile is still unknown.

Our Group II isolates exhibit a different TE composition than previously described from grapevine in France, where only transposa and Group II-vacuma isolates were found $(19,21)$. In B. cinerea populations collected in Bordeaux vineyards (40), four TE genotypes within the Group II were described in very different proportions: transposa (59.8\%), Boty (21.3\%), vacuma (15.5\%), and Flipper (1.1\%). Nonetheless, Flipper isolates are reported from Thompson seedless in Chile, albeit at low frequencies $(3,54)$. Indeed, the TE composition of Group II and the relative proportions of TE genotypes are not consistent among all studies, and are thus more complex than was initially believed. For example, the situation described in Bordeaux (59\% transposa, 21\% Boty, 16\% vacuma, and $1 \%$ Flipper) compared with those described in California (84\% transposa and $16 \%$ Boty; 41) and in Hungary $(70 \%$ transposa, while Boty, vacuma, and Flipper were present at $10 \%$ each; 59). Factors affecting the composition of $B$. cinerea Group II are not clear at this moment, but environment and fitness could be involved. In fact, transposa isolates have been described as significantly more virulent than vacuma isolates when tested in grape berries (41). Moreover, temperatures near $0^{\circ} \mathrm{C}$ had a negative effect on the aggressiveness of Boty and vacuma isolates, but did not affect the aggressiveness of transposa isolates (13).

Recently, inconsistencies between PCR and dot-blot analyses to identify the presence of transposons, especially Flipper, were described (40). Dot-blot hybridization was the first method developed to screen for the presence of both transposons (23), and more convenient PCR assays were later developed for the same purpose $(38,40,47)$. Martinez et al. (40) reported that the PCR primer used to detect Flipper showed a high proportion of false positives among vacuma isolates (81\%) and Boty isolates (33\%). Therefore, it is possible we have been amplifying mutated variants of Flipper, thus overestimating the percentage of transposa isolates. Nonetheless, Boty and vacuma isolates represent less than $5 \%$ of the population, and thus their epidemiological value, at least in Chile, is still marginal.

Identification of Group II isolates has been done following different methods. Initially, PCR-RFLP of the Bc- $h c h$ gene showed a population division into two groups (21), and then a gene genealogy based on three genes was used to definitely demonstrate the division of B. cinerea populations into Groups I and II (19). Since then, definitive identification has been done using a combination of at least three methods: (i) detection of a privative allele (86-bp allele of the microsatellite locus Bc6 [18,20,28]); (ii) sequence similarity of one of the genes used to define the groups (60); and (iii) fenhexamid resistance (19). The latter test was used by Ma and Michailides (38) to classify four Boty isolates into Group I, but no genetic analysis was done to confirm this assumption. Based on the fact that some fenhexamid-resistant isolates have been found to carry the Bc-hch2 allele, and thus belong to Group II (12), fenhexamid resistance alone is not a reliable character to classify $B$. cinerea.

Population structure of $B$. cinerea in Thompson seedless in the Chilean Central Valley is based on geographical origin and phenological stages. Our work is also the first attempt to assess genetic differentiation of $B$. cinerea populations from table grapes in Chile. The region in which this study was carried out involved 16,000 Thompson seedless hectares, without geographical barriers. The three studied locations were dispersed throughout this region. In fact, the more remote locations are $542 \mathrm{~km}$ apart (Punitaqui and Rengo). Using standard population genetics approaches, we found a genetic differentiation of the $B$. cinerea populations related to location (Tables 4 and 5). Results of clustering analysis (Fig. 4) and Mantel test showed that despite the genetic differentiation linked to location, there is not a direct relationship between the geographic and genetic distance of populations. The reasons for this situation are not clear at this moment. Our results could be related to the capability of $B$. cinerea spores to spread between the locations studied. Previously, the genetic differentiation between $B$. cinerea populations from vineyards in the Champagne and Alsace regions in France (260 km apart) was reported to be higher $\left(\mathrm{F}_{s t}=\right.$ 0.176) than between Chile and Champagne $\left(\mathrm{F}_{s t}=0.109\right)$ or between Chile and Alsace $\left(\mathrm{F}_{s t}=0.130\right)(47)$, locations which are about 11,655 km apart. Later, Fournier and Giraud (18), showed that geography has an effect on genetic differentiation of $B$. cinerea populations, but this was not so strong as the effect of differences between plant hosts. In California, populations from two kiwifruit orchards, $160 \mathrm{~km}$ distant, were genetically different, albeit with a low Fst value (38). In Tunisia, a differentiation was found, but this could not be differentiated from sampling location and host plant (28), while no geographical differentiation was described in Hungarian vineyards (59). In California, a high value of gene flow was determined in isolates sampled in locations separated by $2.5 \mathrm{~km}$ (37), but in Bangladesh some clonal lineages were detected in areas as big as $1,000 \mathrm{~m}^{2}(26)$. Finally, environmental conditions such as predominant wind current and human-mediated movement could be involved in $B$. cinerea spores dispersal.

On the other hand, the results obtained in this study also showed that the phenological stages have an effect on the genetic differentiation of Chilean populations of $B$. cinerea collected from table grapes (Tables 5 and 6). To date, this is the first report related to this kind of differentiation in this pathogen. This fact would suggest that the phenological stages of grapes might be acting as a selective pressure, thus selecting those $B$. cinerea isolates more able to develop under such conditions. In this way, the ability to colonize flowers or floral debris may require metabolic and pathogenic abilities different from those required to colonize grape berries. Martinez et al. (41) showed that transposa were more predominant at harvest and vacuma at senescing floral caps. This differential distribution was explained because transposa have showed themselves to be more virulent than vacuma, the latter being more saprotrophic, and thus more capable of colonizing in such an environment $(39,41)$. In our case, the isolates present in the different stages may have differences in virulence/saprotrophy even at the genetic level. In this line, postharvest or storage of fruit represents a very particular abiotic stress condition, which could select a fraction of the $B$. cinerea population. This could explain why genetic differentiation linked to location is more noticeable in isolates collected in postharvest. Physiological differentiation was found between $B$. cinerea isolates collected from kiwi fruit in orchards and in cold storage, but analysis based on PCR-RFLP doesn't show genetic differentiation among both populations (5).

Gray mold control and fungicide resistance. Our results indicate that grapevine phenological stages and environmental condi- 
tions affect gray mold development. Thus, bloom was the most critical stage for $B$. cinerea infection, a finding which has been previously described in grapevines $(25,27,29,42,48,51,52)$. Locations characterized by high relative humidity during the bloom period, which is conducive for gray mold, showed high infections rates (Punitaqui and Rengo, 33.6 and $27.3 \%$, respectively). As expected, in Buin, a location with low relative humidity, the infection rate was quite low (only $5 \%$ ).

Regarding gray mold control, fungicide programs with more than one iprodione application, such as P4 (applications at prebloom and véraison) and P5 (applications at prebloom, véraison, and preharvest), had higher levels of rot in postharvest than programs with one application of iprodione at bloom (P2 and P3), as well as the program with fungicides other than iprodione (P7). Fenhexamid and pyrimethanil applications at véraison and preharvest, respectively, in $\mathrm{P} 2, \mathrm{P} 3$, and P7 likely explain the low infection levels detected in these programs.

Our results indicate that resistance is a stable character under field conditions. Several facts support this conclusion. In all three locations, a large proportion of isolates with high levels of resistance to iprodione were found. In Rengo, the highest frequency of highly resistant isolates and the lowest frequency of sensitive isolates were detected at postharvest. In Punitaqui, the frequency of highly resistant isolates did not change much throughout the season. A high selection pressure of iprodione due to several fungicide applications did not result in increased levels of resistance among isolates. This would indicate that the $B$. cinerea populations in these locations had stable iprodione resistance at the beginning of the season, and under these circumstances it is not possible to generate changes in populations with a greater selection pressure of the fungicide within a season.

\section{Acknowledgments}

We thank Bayer CropScience-Chile for supporting part of this study. Helpful suggestions and comments of an anonymous reviewer are also acknowledged.

\section{Literature Cited}

1. Ahmed, B., and Hamada, W. 2005. Genetic diversity of some Tunisian Botrytis cinerea isolates using molecular markers. Phytopathol. Mediterr. 44(3):300-306

2. Albertini, C., Thébaud, G., Fournier, E., and Leroux, P. 2002. Eburicol 14 $\alpha-$ demethylase gene (cyp51) polymorphism and speciation in Botrytis cinerea. Mycol. Res. 106:1171-1178.

3. Auger, J., Rodríguez, C., and Esterio, M. 2010. Correlation between the Botrytis cinerea population composition and the latent infection in four table grape cvs. in Chile. Page 31 in: Proc. XVth International Botrytis Symposium, Cádiz, Spain.

4. Bainbridge, B. W., Sreadbury, C. L., Scalise, F. G., and Cohen, J. 1990. Improved method for the preparation of high molecular weight DNA from large and small-scale cultures of filamentous fungi. FEMS Microbiol. Lett. 66:113-118.

5. Baraldi, E., Bertolini, P., Chierici, E., Trufelli, B., and Luiselli, D. 2002. Genetic diversity between Botrytis cinerea isolates from unstored and cold stored kiwi fruit. J. Phytopathol. 150:629-635.

6. Baroffio, C. A., Siegfried, W., and Hilber, U. W. 2003. Long-term monitoring for resistance of Botryotinia fuckeliana to anilinopyrimidine, phenylpyrrole, and hydroxyanilide fungicides in Switzerland. Plant Dis. 87:662-666.

7. Beever, R. E., Laracy, E. P., and Pak, H. A. 1989. Strains of Botrytis cinerea resistant to dicarboximide and benzimidazole fungicides in New Zealand vineyards. Plant Pathol. 38:427-437.

8. Brent, K. J. 1995. Fungicide resistance in crop pathogens: How can it be managed? FRAC. Monogr. $\mathrm{N}^{\circ} 1$, GIFAP, Brussels.

9. Choquer, M., Fournier, E., Kunz, C., Levis, C., Pradier, J. M., Simon, A., and Viaud, M. 2007. Botrytis cinerea virulence factors: New insights into a necrotrophic and polyphageous pathogen. FEMS Microbiol. Lett. 277:1-10.

10. De Miccolis Angelini, R. M., Milicevic, T., Natale, T., Lepore, P., De Guido, A., Pollastro, M. A., Cvjetkovic, B., and Faretra, F. 2003. Botryotinia fuckeliana isolates carrying different transposons show differential response to fungicide and localization on host plant. J. Plant Pathol. 85:288-289.

11. De Waard, M. A., Andrade, A. C., Hayashi, K., Schoonbeek, H. J., Stergiopoulos, I., and Zwiers, L. H. 2006. Impact of fungal drug transporters on fungicide sensitivity, multidrug resistance and virulence. Pest Manag. Sci. 62:195-207.

12. Esterio, M., Auger, J., Ramos, C., and García, H. 2007. First report of fenhexamid resistant isolates of Botrytis cinerea on grapevine in Chile. Plant Dis. 91:768.

13. Esterio, M., Auger, J., Ramos, C., Muñoz, G., and Lizana, L. A. 2005. Ge- netic and phenotypic characterization of Botrytis cinerea Pers., sclerotial isolates recovered from two Thompson Seedless table grapes located in the Central Valley of Chile. Page 114 in: Proc. $43^{\mathrm{d}}$ Southern African Society for Plant Pathology Congress, Hartenbos, South Africa.

14. Excoffier, L., Laval, G., and Schneider, S. 2005. Arlequin ver. 3.0: An integrated software package for population genetics data analysis. Evol. Bioinform. Online 1:47-50.

15. Faretra, F., and Pollastro, S. 1996. Genetic studies of the phytopathogenic fungus Botryotinia fuckeliana (Botrytis cinerea) by analysis of ordered tetrads. Mycol. Res. 100:620-624.

16. Fekete, É., Fekete, E., Karaffa, L., Irinya, L., and Sándor, E. 2010. Characterisation of Hungarian Botrytis cinerea group I isolates. Page 30 in: Proc. XVth International Botrytis Symposium, Cádiz, Spain.

17. Forster, B., and Staub, T. 1996. Basis for use strategies of anilinopyrimidine and phenylpyrrole fungicides against Botrytis cinerea. Crop Prot. 15:529537.

18. Fournier, E., and Giraud, T. 2008. Sympatric genetic differentiation of a generalist pathogenic fungus, Botrytis cinerea, on two different host plants, grapevine and bramble. J. Evol. Biol. 21:122-132.

19. Fournier, E., Giraud, T., Albertini, A., and Brygoo, Y. 2005. Partition of the Botrytis cinerea complex in France using multiple gene genealogies. Mycologia 97:1251-1267.

20. Fournier, E., Giraud, T., Loiseau, A., Vautrin, D., Estoup, A., Solignac, M., Cornuet, J. M., and Brygoo, Y. 2002. Characterization of nine polymorphic microsatellite loci in the fungus Botrytis cinerea (Ascomycota). Mol. Ecol Notes 2:253-255.

21. Fournier, E., Levis, C., Fortini, D., Leroux, P., Giraud, T., and Brygoo, Y. 2003. Characterization of $\mathrm{Bc}-h c h$, the Botrytis cinerea homolog of the Neurospora crassa het-c vegetative incompatibility locus, and its use as a population marker. Mycologia 95:251-261.

22. Giraud, T., Fortini, D., Levis, C., Lamarque, C., Leroux, P., LoBuglio, K., and Brygoo, Y. 1999. Two sibling species of the Botrytis cinerea complex, transposa and vacuma, are found in sympatry on numerous host plants. Phytopathology 89:967-973.

23. Giraud, T., Fortini, D., Levis, C., Leroux, P., and Brygoo, Y. 1997. RFLP markers show genetic recombination in Botryotinia fuckeliana (Botrytis cinerea) and transposable elements reveal two sympatric species. Mol. Biol. Evol. 14:1177-1185.

24. Hilber, U. W., and Hilber-Bodmer, M. 1998. Genetic basis and monitoring of resistance of Botryotinia fuckeliana to anilinopyrimidines. Plant Dis. 82:496-500.

25. Holz, G., Gütschow, M., Coertze, S., and Calitz, F. J. 2003. Ocurrence of Botrytis cinerea and subsequent disease expression at different positions on leaves and bunches of grape. Plant Dis. 87:351-358.

26. Isenegger, D. A., Macleod, W. J., Ford, R., and Taylor, P. W. J. 2008. Genotypic diversity and migration of clonal lineages of Botrytis cinerea from chickpea fields of Bangladesh inferred by microsatellite markers. Plant Pathol. 57:967-973.

27. Jarvis, W. R. 1980. Epidemiology. Pages 219-250 in: The Biology of Botrytis. J. R. Coley-Smith, K. Verhoeff, and W. R. Jarvis, eds. Academic Press, London.

28. Karchani-Balma, S., Gautier, A., Raies, A., and Fournier, E. 2008. Geography, plants, and growing systems shape the genetic structure of Tunisian Botrytis cinerea populations. Phytopathology 98:1271-1279.

29. Keller, M., Viret, O., and Cole, F. M. 2003. Botrytis cinerea infection in grape flowers: Defense reaction, latency, and disease expression. Phytopathology 93:316-322.

30. Krestchmer, M., and Hahn, M. 2008. Fungicide resistance and genetic diversity of Botrytis cinerea isolates from a vineyard in Germany. J. Plant Dis. Prot. 115(5):214-219.

31. Latorre, B., Flores, V., Sara, A., and Roco, A. 1994. Dicarboximide-resistant strains of $B$. cinerea from table grapes in Chile: Survey and characterization. Plant Dis. 78:990-994.

32. Leroux, P., Chapeland, F., Desbrosses, D., and Gredt, M. 1999. Patterns of cross-resistance to fungicides in Botryotinia fuckeliana (Botrytis cinerea) isolates from French vineyards. Crop Prot. 18:687-697.

33. Leroux, P., and Clerjeau, M. 1985. Resistance of Botrytis cinerea Pers. and Plasmopara viticola (Berk. \& Curt.) Berl. and de Toni to fungicides in French vineyards. Crop Prot. 4(2):137-160.

34. Leroux, P., and Gredt, M. 1981. Méthode de détection de la résistance de $B$. cinerea Pers., aux fongicides, a partir d'echantillons prélevés dans le vignoble. Phytiatrie-Phytopharm. 30:57-68.

35. Leung, H., Nelson, R. J., and Leach, J. A. 1993. Population structure of plant pathogenic fungi and bacteria. In: Advances in Plant Pathology, Vol. 10:157-205. J. H. Andrews and I. C. Tommeup, eds. Academic Press, San Diego.

36. Liedloff, A. 1999. Mantel Nonparametric Test Calculator for windows (version 2.00). Queensland University of Technology, Brisbane.

37. Lorbeer, J. W. 1980. Variation in Botrytis and Botryotinia. Pages 19-39 in: The Biology of Botrytis. J. R. Coley-Smith, K. Verhoeff, and W. R. Jarvis, eds. Academic Press, London.

38. Ma, Z., and Michailides, T. J. 2005. Genetic structure of Botrytis cinerea populations from different host plants in California. Plant Dis. 89:10831089. 
39. Martinez, F., Blancard, D., Lecomte, P., Levis, C., Dubos, B., and Fermaud, M. 2003. Phenotypic differences between vacuma and transposa subpopulations of Botrytis cinerea. Eur. J. Plant Pathol. 109(5):479-488.

40. Martinez, F., Corio-Costet, M. F., Levis, C., Coarer, M., and Fermaud, M. 2008. New PCR primers applied to characterize distribution of Botrytis cinerea populations in French vineyards. Vitis 47:217-226.

41. Martinez, F., Dubos, B., and Fermaud, M. 2005. The role of saprotrophy and virulence in the population dynamics of Botrytis cinerea in vineyards. Phytopathology 95:692-700.

42. McClellan, W. D., and Hewitt, W. 1973. Early Botrytis rot of Grapes: Time of infection and latency of $B$. cinerea Pers. in Vitis vinifera L. Phytopathology 63:1151-1157.

43. McDonald, B. A., and Linde, C. C. 2002. Pathogen populations genetics, evolutionary potential and durable resistance. Annu. Rev. Phytopathol. 40:349-379.

44. Milicevic, T., Cvjetkovic, B., Topolovec-Pintaric, S., Faretra, F., Pollastro, S., and De Miccolis Angelini, R. M. 2004. Dynamics of sympatric subpoulations of Botrytis cinerea in different phenophases of grapevine in Croatian vineyards and their connection to resistance to botryticides. Page 27 in: Proc. XIIIth International Botrytis Symposium, Antalya, Turkey.

45. Mlikota Gabler, F., Smilanick, J. L., Mansour, M., Ramming, D. W., and Mackey, B. E. 2003. Correlations of morphological, anatomical, and chemical features of grape berries with resistance to Botrytis cinerea. Phytopathology 93:1263-1273.

46. Muñoz, G., Hinrichsen, P., and Alvarez, M. 1999. Caracterización microbiológica y variabilidad genética de cepas de $B$. cinerea resistentes a dicarboximidas provenientes de vid y tomate. Agric. Téc. 59:1-12.

47. Muñoz, G., Hinrichsen, P., Brygoo, Y., and Giraud, T. 2002. Genetic characterization of Botrytis cinerea populations in Chile. Mycol. Res. 106:594601.

48. Nair, N. G., and Allen, R. N. 1993. Infection of grape flowers and berries by Botrytis cinerea as a function of time and temperature. Mycol. Res. 97:1012-1014

49. Nei, M. 1978. Estimation of average heterozygosity and genetic distance from small number of individuals. Genetics 89:583-590.
50. Nei, M. 1987. Molecular Evolutionary Genetics. Columbia University Press, New York.

51. Pezet, R., and Pont, V. 1986. Infection floral et latence de Botrytis cinerea dans les grapes de Vitis vinifera (var. Gamay). Rev. Suisse Vitic. Arboric. Hortic. 18(5):317-322.

52. Pezet, R., Viret, O., Perret, C., and Tabacchi, R. 2003. Latency of Botrytis cinerea Pers., Fr. and biochemical studies during growth and ripening of two grape berry cultivars, respectively susceptible and resistant to gray mold. J. Phytopathol. 151:208-214.

53. Pommer, E. H., and Lorenz, G. 1982. Resistance of Botrytis cinerea Pers. to dicarboximide fungicides - A literature review. Crop Prot. 1:221-230.

54. Ramos, C. 2010. Caracterización genética de poblaciones de Botrytis cinerea recuperadas de restos florales senescentes en vides cv. Thompson Seedless. Tesis Magíster en Ciencias Silvoagropecuarias. Facultad de Ciencias Agronómicas, Universidad de Chile, Santiago, Chile.

55. Rosslenbroich, H., and Stuebler, D. 2000. Botrytis cinerea - History of chemical control and novel fungicides for its management. Crop Prot. 19:557-561.

56. Sneath, P., and Sokal, R. 1973. Numerical taxonomy: The principles and practices of numerical classification. Freeman \& Co., San Francisco.

57. Sokal, R. R., and Rohlf, F. J. 1995. Biometry. 3rd ed. W.H. Freeman \& Co., New York.

58. Tamura, K., Dudley, J., Nei, M., and Kumar, S. 2007. MEGA4: Molecular Evolutionary Genetics Analysis (MEGA) software version 4.0. Mol. Biol. Evol. 24:1596-1599.

59. Váczy, K. Z., Sándor, E., Karaffa, L., Fekete, E., Fekete, É., Árnyasi, M., Czeglédi, L., Kövics, G. J., Druzhinina, I. S., and Kubicek, C. P. 2008. Sexual recombination in the Botrytis cinerea populations in Hungarian vineyards. Phytopathology 98:1312-1319.

60. Williamson, B., Tudzynski, B., Tudzynski, P., and van Kan, J. A. L. 2007. Botrytis cinerea: The cause of grey mould disease. Mol. Plant Pathol. 8:561-580.

61. Yeh, F. C., Yang, R. C., Boyle, T. B. J., Ye, Z. H., and Mao, J. X. 1999. POPGENE, the user-friendly shareware for population genetic analysis. Molecular Biology and Biotechnology Center, University of Alberta, Canada. 